\title{
The radial artery for coronary artery bypass grafting
}

D. Nezic ${ }^{1}$, P. Milojevic ${ }^{1}$, M. Cirkovic ${ }^{1}$, A. Knezevic ${ }^{1}$,

A. Novakovic ${ }^{2}$, Lj. Gojkovic-Bukarica ${ }^{3}$, M. Jovic ${ }^{1}$,

B.Djukanovic ${ }^{1}$,

${ }^{1}$ Dedinje Cardiovascular Institute, Belgrade,

${ }^{2}$ Department of Pharmacology, Faculty of Pharmacy,

3Department of Clinical Pharmacology, Pharmacology and

Toxicology, Medical School, Belgrade

Coronary artery bypass grafting (CABG) is the standard surgical procedure for the treatment of advanced coronary artery disease. CABG surgery has been demonstrated to improve symptoms and, in specific subgroups of patients, to prolong life. Despite its success, the long-term outcome of coronary bypass surgery is strongly influenced by the fate of the vascular conduits used. Previous long-term studies have shown unsatisfactory patency of saphenous vein grafts used for myocardial revascularisation, compared with internal mammary artery grafts. Recently, the use of radial artery for CABG has enjoyed a revival, on the basis of the belief that it will help improving long-term results of coronary operations. The recent reports of encouraging mid-term and long-term patency rates of the radial artery, supports its continued use as a bypass conduit. In this paper, we review the current knowledge about the radial artery as a bypass graft, with special emphasis on the clinical results.

Key words: surgical myocardial revascularisation, radial artery conduit

\section{INTRODUCTION}

The

The clinical and prognostic benefits of coronary artery bypass grafting (CABG) for some subgroups of patients with ischemic heart disease are well accepted, and worldwide every year almost 1 million patients undergo coronary revascularisation. ${ }^{1} \mathrm{CABG}$ provides excellent short and intermediate-term results, but long-term outcome is strongly influenced by the fate of the vascular conduits used.

Ten years after CABG, $90 \%$ of internal thoracic artery (ITA) grafts are patent and disease free while $75 \%$ of saphenous vein grafts (Svg) are occluded or severely stenosed. ${ }^{2}$ Within the first month after coronary bypass surgery venous grafts may occlude due to thrombosis and/or technical failure. Between 1 month and 1 year after operation, intimal hyperplasia takes place in still open graft.
Thereafter, the development of atherosclerosis in the vein grafts starts which accelerates after the fifth post-operative year. ${ }^{3,4}$ The attrition rate of venous grafts is highest, $8 \%$ to $12 \%$ within the first 4 weeks after CABG. By the end of the first year, $12 \%$ to $20 \%$ of the saphenous vein grafts have been occluded. In the following 4 years the attrition rate is low ( $1 \%$ to $2 \%$ per year), but thereafter graft closure is 2 times more frequent. By 10 years postoperatively about $50 \%$ of the venous grafts have closed, and $25 \%$ have been severely stenosed. ${ }^{3,4}$

Impressive long-term patency of the LITA-LAD (left anterior descending coronary artery) graft, coupled with proven long-term survival benefit, has led to its becoming a "golden standard" of CABG. Multiple groups have reported significantly better CABG survival when both ITA conduits are used concomitantly compared with a single ITA. ${ }^{1,5,6}$ Death, reoperation and percutaneous transluminal coronary angioplasty were significantly more frequent for patients undergoing single rather than bilateral ITA grafting.

Thus, the use of arterial conduits has expanded beyond the ITAs to include the right gastroepiploic artery, the inferior epigastric artery and the radial artery. The assumption is that although the performance of one or two arterial ITA graft is good, more arterial grafts should perform better.

Several studies have documented excellent clinical results and satisfactory short and mid-term patency rates at restudy angiography of radial artery conduits used for CABG. ${ }^{7.8 .9}$. One long-term angiographic study has demonstrated disease-free patency rate of the radial artery graft of $88 \%$, nine years after surgery, 10 promoting radial artery conduit as second or third arterial graft of choice in coronary revascularisation.

\section{HISTORICAL NOTE}

Carpentier and colleagues11 first introduced the radial artery (RA) for myocardial revascularisation in 1971. Un- 
fortunately, high occlusion rates were reported and the utilisation of the RA was almost completely abandoned. Early graft failures were attributed to graft vasospasm and premature occlusions to intimal hyperplasia, likely the result of endothelial denudation from mechanical dilatation and trauma of technically imperfect skeletonized harvesting. In 1992, Acar and colleagues ${ }^{12}$ strongly recommended the use of RA having detected several patent RA grafts up to 18 years after the initial myocardial revascularisation and due to excellent early patency of RA $(100 \%, 56$ patients) in their sample. Encouraging early and mid-term patency rates were obtain during this revival of radial artery conduit, and were ascribed to an improved harvesting technique, together with the use of calcium channel blockers or other vasodilators to prevent perioperative spasm of the graft. These reports led many other groups to reassess the role of this conduit in coronary bypass procedures.

\section{ADVANTAGES OF THE RADIAL ARTERY CONDUIT}

Several anatomopathological features present the radial artery conduit as an excellent graft to be used in coronary revascularisation:

a) it is easy to harvest it parallel with the ITA;

A standard incision (nondominant arm) over the RA is used to facilitate harvesting from its origin in the proximal forearm $(3 \mathrm{~cm}$ distal to the elbow crease, lateral to the biceps tendon) to $1 \mathrm{~cm}$ before the proximal crease at the wrist level, centred over the radial pulsation, between the flexor carpi radialis and the radial tubercle. After incision of the skin, low-current diathermy is used for the subcutaneous tissue and deep fascia in the proximal third of the forearm (the RA is well away from the fascia). The deep fascia in the distal forearm is incised with scissors to avoid thermal injury as the artery became more superficial. A self-retaining retractor is used to separate the brahioradialis and flexor carpi muscles, and a silicone elastomer vessel loop is placed around the radial artery pedicle (including the radial artery venous comitantes) to facilitate handling, mobilisation and dissection of the pedicle (Figure 1.). The branches of the RA are divided between small clips using scissors. In the patients undergoing ultrasonic dissection of the RA pedicle, the sharppointed hook blade (moderate intensity, the variable mode) is used. Branches that bled during or after transection are controlled with small clips. Care is also taken to avoid damaging the lateral antebrachial cutaneous (sensory) nerve (it lies at the level of the fascia enveloping the brachioradialis muscle at its volar border and supplies the skin of the radial aspect and adjacent dorsal surface of the forearm), as well as the superficial radial (sensory) nerve. It travels beneath the brachioradialis muscle and parallel to the RA in its proximal and middle third, supplying the dorsal skin of the thumb ${ }^{13,14}$.

b) it is long enough to be used as a conduit to any coronary territory;

The average RA length suitable for bypass and capable to reach any coronary artery territories, varies between 18 and $22 \mathrm{~cm} .{ }^{15}$ Harvested in skeletonized fashion, RA appeared to be even longer than harvested as the pedicled

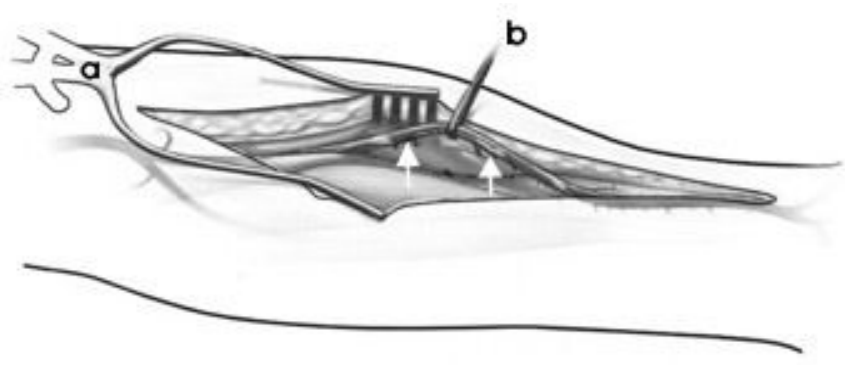

Figure 1.

RADIAL ARTERY HARVESTING (a - SELF-RETAINING RETRACTOR , b - SILICONE ELASTOMER VESSEL LOOP, /RADIAL ARTERY - WHITE ARROWS)

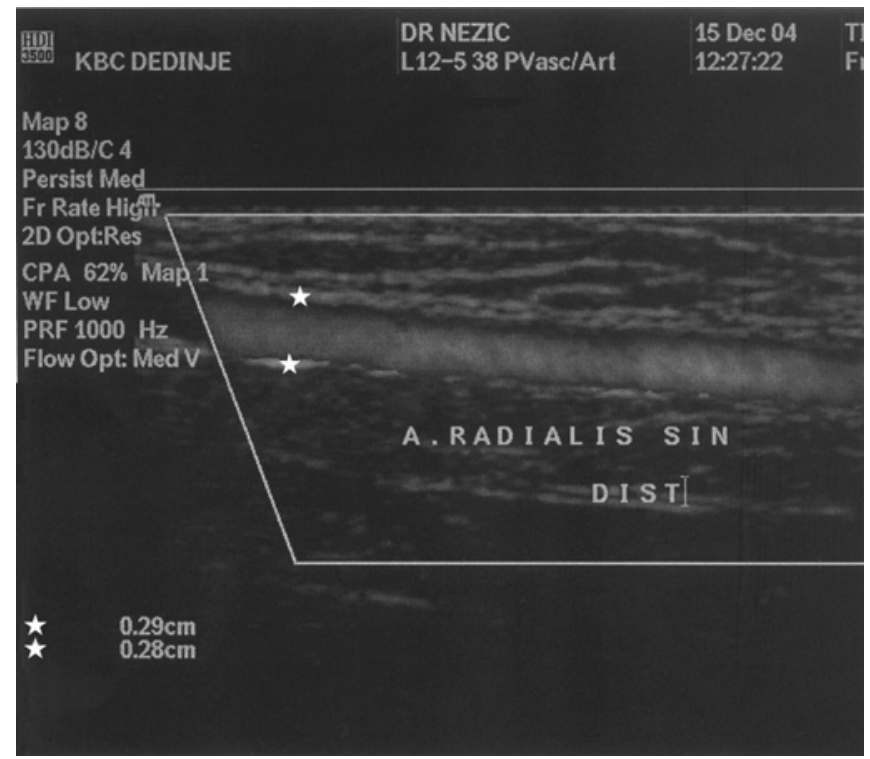

Figure 2.

DOPPLER ULTRASONOGRAPHY OF THE RADIAL ARTERY (RADIAL ARTERY DIAMETER - WHITE STARS)

graft $^{16}$. Radial artery graft is free from internal valves (unlike saphenous vein graft), so bi-directional blood flow is possible and RA can be used so as to create an "'anastomotic network" between the coronary artery territories. The ends of the RA are anastomosed in an end-to-side fashion to different coronary arteries. Then the RA is attached in a side-to-side fashion to the LITA, ${ }^{17}$ or to the ascending aorta (a Cabrol-type-proximal anastomosis technique), ${ }^{18}$ thus forming the anastomotic network. 
TABLE 1

MID-TERM RADIAL ARTERY CONDUIT ANGIOGRAPHIC PATENCY

\begin{tabular}{|c|c|c|c|c|c|c|}
\hline \multirow{2}{*}{ Authors } & \multirow{2}{*}{ Study design } & \multirow{2}{*}{$\begin{array}{l}\% \text { of pts } \\
\text { reassessed }\end{array}$} & \multicolumn{3}{|c|}{ Angiographic patency } & \multirow{2}{*}{$\begin{array}{l}\text { Years to } \\
\text { reangiogram }\end{array}$} \\
\hline & & & $\mathrm{Ra}$ & Svg & Rita & \\
\hline Bhan 1999 & retrospective & $21.6(62 / 287)$ & $96.8 \%(60 / 62)$ & & & $1.4 \pm 0.4$ \\
\hline Iaco 2001 & retrospective & $43.9(72 / 164)$ & $95.6 \%(87 / 91)^{*}$ & $88.8 \%(8 / 9)$ & & $4.0 \pm 2.3$ \\
\hline $\begin{array}{l}\text { Calafiore } \\
2002\end{array}$ & retrospective & $19.8(57 / 288)$ & $99.0 \%(100 / 101)^{*}$ & $91.7 \%(11 / 12)$ & $100 \%(5 / 5)$ & $2.9 \pm 2.3$ \\
\hline Khot 2004 & retrospective & $?(310 / ?)$ & $53.1 \%(204 / 398)^{*}$ & $64.0 \%(174 / 272)$ & $79.2 \%(61 / 77)$ & $1.6 \pm 1.4$ \\
\hline $\begin{array}{l}\text { Zachariax } \\
2004\end{array}$ & $\begin{array}{l}\text { retrospective, } \\
\text { propensity sc. }\end{array}$ & $20.5(190 / 925)$ & $68.2 \%(165 / 242)^{*}$ & $63 / 3 \%(372 / 588)$ & & $1.8 \pm 1.4$ \\
\hline Shah 2005 & retrospective & $4.5(219 / 4872)$ & $90.6 \%(329 / 363) *$ & $88.9 \%(40 / 45)$ & $94.4 \%(51 / 54)$ & $3.0 \pm 2.0$ \\
\hline Desai 2004 & $\begin{array}{l}\text { prospective, } \\
\text { randomized }\end{array}$ & $78.4(440 / 581$ & $\begin{array}{l}\text { perfect p } 91 / 8 \% \\
\text { siring sign } 7.0 \%\end{array}$ & $\begin{array}{l}\text { perfect p. } 86.5 \% \\
\text { siring sign } 0.9 \%\end{array}$ & & $0.9 \pm 0.4$ \\
\hline
\end{tabular}

c) it is adapted to higher arterial pressures and large enough in calibre to match the most of the coronary arteries;

d) it is easy to handle due to its thick muscular wall;

The RA is a thick-walled muscular artery (type III artery due to He's classification ${ }^{19}$ of arterial grafts according to their physiologic and embryologic properties) and its inner diameter varies between 2 to $3 \mathrm{~mm} .{ }^{14,15}$ The intima has one layer of endothelial cells beneath, where multiple layers of subendothelial cells, and small amount of myocytes, are present. The internal elastic lamina has multiple fenestrations, and the media is constituted by many leiomyocytes, elastic and collagen fibres, fibroblasts and rare macrophages. The external lamina is less individualised than the internal lamina. Some evidence suggests that the vasa vasorum, nerves and lymphatic vessels are confident to the adventitia, while others describe vasa vasorum penetration into RA media (superficial layers) ${ }^{15}$.

e) it can be harvested in a majority of patients (obesity, diabetes mellitus, chest wall and mediastinal radiation or previous laparotomy do not apply to radial artery harvesting).

\section{POTENTIAL DISADVANTAGES OF THE RADIAL AR- TERY CONDUIT}

Removal of the radial artery poses the risk of ischemic complications to the hand, particularly the thumb and index finger, which could be deprived of flow in individuals with anatomic arterial variations that do not allow adequate collateral flow across the palm. The anatomic feature that permits harvesting of RA is the presence of anastomoses across the hand between the radial and ulnar arteries, in the form of several arches. The most important pathway is the superficial palmar arch, which typically originates from the ulnar artery and provides the majority of arterial supply to the digits. If the superficial palmar arch is intact, than collateral flow to the radial aspect of the hand should be adequate if the RA is removed. However, there are several anatomic variants that may lead to hand ischemia with RA harvesting. These include an incomplete superficial palmar arch, RA dominance of the superficial palmar arch and absence or malformation of the ulnar artery. The frequency of an incomplete superficial palmar arch is reported to range from $6 \%$ to $34 \% 20$. Although additional data about collateral circulation, ulnar or radial artery agenesis can be detected using the Doppler ultrasound (Fig. 2.), angiographic examination is still the gold standard21. Thus, before harvesting the RA it is mandatory to assess the adequacy of the ulnar collateral circulation to the hand. Methods to detect adequate forearm collateral flow include the clinical modified Allen test, pulse oximetry, digital blood pressure measurement, flow measurement with photoplethysmography, segmental pressure measurements, laser Doppler flowmetry, modified Allen test with Doppler ultrasonography and color Doppler with pulsed wave spectral trace of flow. ${ }^{14,20,22}$

At present, most studies have examined the Allen test or a variation on this test as an index of the immediate safety for harvesting the RA.

Using clinically modified Allen's test the ulnar and radial arteries are compressed at the wrist for $\geq 30$ seconds (s) to induce hand ischemia. Blood is evacuated from the hand by clenching. The ulnar artery is released and if hyperaemic reperfusion at the tips of the thumb and index fingers occurs $\leq 5 \mathrm{~s}$, then the test is called "normal" and the RA harvested. If reperfusion occurs after 6-10 s, then the test is called "equivocal" and mostly the RA is used. But if the reperfusion occurs $>10 \mathrm{~s}$, then the test is deemed "abnormal" and the RA is not used. ${ }^{23}$

Using pulse oximetry a pulse oximeter sensor is placed on the thumb of the planned donor extremity (usually nondominant arm). If the oxygen saturation exceeds $90 \%$, both ulnar and radial arteries are compressed at the wrist 
TABLE 2

LONG-TERM RADIAL ARTERY CONDUIT ANGIOGRAPHIC PATENCY

\begin{tabular}{|c|c|c|c|c|c|c|}
\hline \multirow{2}{*}{ Authors } & \multirow{2}{*}{ Study design } & \multirow{2}{*}{$\begin{array}{l}\% \text { of pts } \\
\text { reassessed }\end{array}$} & \multicolumn{3}{|c|}{ Angiografphic patency } & \multirow{2}{*}{$\begin{array}{l}\text { Years to } \\
\text { reangiogram }\end{array}$} \\
\hline & & & $\mathrm{Ra}$ & Svg & Rita & \\
\hline Acar 1998 & retrospective & $5.5(50 / 910)$ & $82.8 \%(53 / 64)^{*}$ & & & $5.6 \pm 1.1$ \\
\hline Possati 1998 & prospective & $20.9(68 / 325)$ & $88.6 \%(55 / 62)$ & $74.0 \%(43 / 58)$ & $75.0 \%(3 / 4)$ & $4.9 \pm 0.5$ \\
\hline Possati 2003 & prospecitive & $27.7(90 / 235)$ & $90.5 \%(76 / 84)$ & $67.1 \%(49 / 73)$ & $85.7 \%(6 / 7)$ & $8.8 \pm 1.0$ \\
\hline Buxton 2003 & $\begin{array}{l}\text { prospective,randomi } \\
\text { zed II groups, Ra } \\
\text { vs Frita or Svg }\end{array}$ & $\begin{array}{l}\text { Ra } 27.9 \\
\text { Frita } 20.0 \\
\text { Ra } 32.9 \\
\text { Svg } 27.5\end{array}$ & $87.5 \%(21 / 24)$ & $95.5 \%(21 / 22)$ & $100 \%(29 / 29)$ & $5.0 \pm 1.0$ \\
\hline $\begin{array}{l}\text { Cameron } \\
2004\end{array}$ & retrospective & $16.7(50 / 300)$ & $88.7 \%(55 / 62)^{*}$ & $91.7 \%(33 / 36)$ & $94.4 \%(17 / 18)$ & $5.2 \pm 0.4$ \\
\hline
\end{tabular}

until the oxymetric signal is lost. If release of the distal ulnar flow results in a return of the pulse oximeter signal to the base line value within 10 seconds, collateral flow is deemed adequate for radial artery usage. ${ }^{24}$

Concerns with the adequacy of forearm collateral circulation, raised by the preoperative testing method, have excluded RA harvest unilaterally in range from $5 \%$ to 11.6 $\%$, and bilaterally in range from $5 \%$ to $6.4 \%$ of patients who are candidates for RA harvest. ${ }^{15}$

If there are no other contraindications before harvesting (RA plaque on ultrasound, damaged RA due to trauma of previous canullations, the presence of an arterio-venous fistula for haemodialysis, vasculitis, carpal tunnel syndromas or Raynaud's disease), removal of the RA does not results in any symptoms of hand ischemia or motor dysfunction. Some studies ${ }^{21,22}$ have confirmed enhanced flow in the remaining artery to the forearm (immediately after RA was harvested) with no acute dilatation of that artery. Mid-term as well as long-term follow-up studies (few to 36 months) ${ }^{21,22,25,26}$ have demonstrated chronic enlargement of the remaining artery (ulnar artery ${ }^{22}$ or rather interosseous artery ${ }^{21}$ ) or a statistically significant increase of mean peak systolic flow velocity in ulnar artery (compared with the preoperative value) ${ }^{26}$, to compensate blood supply of the forearm.

Although acute hand ischemia with serious motor deficiency (requiring surgical reintervention), was reported in two articles, de facto the same case report (coming from the same hospital, presenting the same patient with identical angiographic material) was published twice, presented by different authors. ${ }^{27,28}$ In that single case angiographic examination confirmed ulnar artery agenesis, although perioperative tests established that there was good perfusion to the hand via the collateral vessels. Circulation was restored by performing brachioradial bypass grafting using reversed cephalic vein. 27,28
The most common complications noted, occurring in $2.6 \%$ to $15.2 \%$ of patients, ${ }^{13,22,24}$ are sensory abnormalities, especially cutaneous paresthesis and/or numbness in the radial distribution of sensory nerves (lateral antebrachial cutaneous nerve, superficial branch of the radial nerve) due to nerve injury from direct trauma, oedema or carpal tunnel haematoma. Long-term persistence of the symptoms $(4.2 \pm 2.1 \text { years postoperatively })^{13,24}$ were recorded in $10 \%$ of the patients, but were considered a "constant and significant source of discomfort" in only $1 \%$ of patients. Fortunately, most patients tolerated sensory loss and subjective thumb weakness without a significant limitation in hand activities.

Patients who had undergone endoscopic RA harvesting have been reported to have significantly fewer major complications (haematomas, wound infections, neuralgias) than patients who underwent the open RA harvesting technique. ${ }^{29,30}$ The integrity of the conduit has not been altered, as demonstrated by the histological findings of the conduit. Although the technique is appealing, the long term patency rates of endoscopically harvested RA have yet to be reported.

In patients with coronary artery disease, RA atherosclerotic involvement is more frequent (up to 6.9 $\%)^{31,32,33}$ than that of the gold standard ITA. Factors associated with an increased likelihood of medial calcification and atherosclerosis included a history of smoking, diabetes, hypercholesterolemia, peripheral artery disease and chronic renal failure $(p<0.05) .{ }^{32}$ The RA that is heavily calcified poses technical difficulties intraoperatively apart from indicating a doubtful long-term patency. However, Gaudino and colleagues ${ }^{33}$ have reported that the early atherosclerotic signs, observed very often in RA using subtle histopathological or echographic methods do not seem to have the potential to influence midterm RA graft patency (93.3\% at a mean interval of $61 \pm 7$ months) and endothelial function. 
The RA is expected to be more vasospastic compared to other arterial grafts due to its characteristics of being a type III artery and of having predominantly - adrenergic receptors. Thus, the propensity for the RA to go into spasm is likely due to the higher density of muscle cells in the media of this vessel (organised into multiple tight layers compared with ITA, gastroepiploic and epigastric arteries with fewer muscle cells that are less organised) ${ }^{34}$ resulting in a significantly higher maximal contractile force in response to vasoconstricting agents. Those agents include norepinephrine, serotonin, endothelin I and angiotensin II generated in response to endothelial damage and dysfunction due to inflammatory response to cardiopulmonary bypass or surgical stress, as well as exogenously administered inotropes or vasoconstrictors. 15,35 He and Yang $^{36}$ have suggested that the RA propensity toward spasm is not solely a function of the muscular wall but that an enhanced reactivity to afore-mentioned vasoactive mediators is of key importance. Vasospasm has been reported in $4 \%$ to $10 \%$ of all RA grafts. ${ }^{35}$

It is commonly agreed upon that RA harvest must be performed with gentle mobilisation of the RA, with light tractions, minimal touch and minimal diathermy or ultrasonic dissection, thus diminishing endothelial trauma related to harvesting process. Currently, the propensity of the RA to spasm has greatly been reduced using topically different categories of vasodilators, including calcium channel blockers, the phosphodiesterase (papaverin-short acting, and milrinone-long acting) ${ }^{35}$ inhibitors, -adrener gic antagonists (i.e. phenoxybenzamin) ${ }^{37}$ as well as drug mixtures such as verapamil and nitroglycerin (VNG) or verapamil and papaverine. ${ }^{14,15}$ Clinically useful agents should ideally be effective against a wide variety of endo and egzogenously delivered substances causing receptormediated as well as receptor-independent vasoconstriction of the RA graft. ${ }^{37}$ Furthermore, antispasmodic activity should be maintained throughout the immediate postoperative period. Currently, no single topical antispasmodic agent fulfils all the criteria necessary to prevent RA vasospasm in clinical practice. VNG solution is effective against a broad range of vasoconstricting agents, but its relatively short duration of effects (up to 5 hours) ${ }^{37}$ limits its usefulness in the clinical practice. Phenoxybenzamin is a more effective agent to prevent - adrenergic spasm, but has little effect on vasoconstriction caused by noncatecholamine vasoactive mediators. Its prolonged duration of action (up to 18 hours in vitro) ${ }^{35}$ as well as the ability to prevent catecholamine mediated vasoconstriction, ${ }^{37}$ recommends it as a useful agent in the immediate postoperative period, especially in $\mathrm{CABG}$ patients requiring inotropic support (dopamine, epinephrine, norepinephrine). Finally, a combination of agents may be appropriate to combat vasospasm of the RA graft and thereby reduce the likelihood of early graft failure. It has recently been shown that adenoviral-mediated gene transfer (suggesting a possible future clinical application), causing overexpresion of nitric oxide synthase in human RA, can minimise RA vasospasm through the inhibition of voltage-dependent as well as receptor-dependent pathways. ${ }^{38}$
In order to prevent delayed vasospasm, oral calcium channel antagonists have been recommended for as long as 1 year after surgery for patients receiving RA conduits. In a prospective, randomised study, Gaudino and colleagues ${ }^{39}$ have confirmed (a 5-year angiographic control study) that continuation of diltiazem beyond 1 year (in patients with RA conduit) provided no additional benefit in terms of clinical and angiographic outcomes. The longterm (109 \pm 9 months) angiographic results of the same cohort of patients have presented no difference in angiographic patency of the RA conduits between those patients who continued versus those who suspended calcium channel blocker therapy. ${ }^{10}$ Furthermore, the same authors have recently presented prospective, randomised study, confirming that calcium channel blocking therapy started immediately after surgery and continued for the first postoperative year did not affect either radial artery conduit patency or clinical outcomes. However, the role of calcium channel blocking therapy in the early postoperative period, when radial artery tendency to spasm is thought to be maximal, has yet to be clarified, and its use remains routine in many centres.

\section{OPTIMAL GRAFTING STRATEGY}

Optimal placement of the radial artery to achieve satisfactory long-term patency has yet to be clarified.

There is accumulating evidence that grafting the RA to coronary targets with moderate stenoses $(<70 \%)$ results in statistically significantly reduced conduit patency. $41,42,43,44$ Furthermore, in prospective, randomised study, Desai and colleagues ${ }^{43}$ have recently presented that targeted coronary arteries with stenosis of $\geq 90 \%$, as compared with those coronary-vessel lesions with stenosis of $70-89 \%$, were associated with a lower rate of occlusion of the radial artery conduit $(5.9 \%$ vs. $11.8 \%, \mathrm{p}=$ $0.03)$, as well as with a lower rate of "string sign" in radial artery grafts $(3.7 \%$ vs. $12.4 \%, \mathrm{p}<0.001)$. The concept of competitive flow suggests that graft flow is influenced by native coronary flow. ${ }^{35}$ Grafted conduits may therefore fare better in conditions of poor native coronary flow, i.e. in the case of high-grade stenosis or occlusion of targeted coronary arteries.

Some studies have identified target location as significant predictor for conduit failure, thus lower angiographic patency rates for RA grafts to both the circumflex and right (statistically significant) coronary arteries were reported. ${ }^{41,42}$ These findings remains controversial, because there are many studies confirming that target vessel location does not influence RA conduit patency. ${ }^{10.43,45}$ There are few options to perform the proximal RA anastomosis. The most commonly used are to the aorta as an aortocoronary conduit or to the another graft (usually ITAs) as a composite conduit (in a $\mathrm{T}$ or $\mathrm{Y}$ fashion). It has been speculated that the histologic and structural characteristics of the RA can render this conduit particularly prone to vessel wall ischemia and consequent intimal proliferation, especially when exposed to the hemodynamic stress due to the sharp increase in $\mathrm{dp} / \mathrm{dt}$ present in the initial part of the ascending aorta. For this reason some authors have advocated performing the proximal anastomosis of RA 
grafts to a vascular region with a lower $\mathrm{dp} / \mathrm{dt}$, such as an ITA graft. $^{46}$

Maniar et colleagues 42 have reported that the site of proximal anastomosis does not appear to influence RA conduit patency. In their study angiographic (average period to reangiogram 26.1 months) RA conduit patency in aortocoronary versus composite configuration demonstrated no statistically significant difference $(72.0 \%$ vs. $70.5 \%)$. Other authors ${ }^{49,48,49}$ have reported excellent mid-term (average period to reangiogram 16.2, 36,8 and 59 months, respectively) RA conduit patency $(96.8 \%$, $90.6 \%$ and $91.9 \%$, respectively) in aortocoronary configuration. Matchless results (patency rate of 99\%) have also been reported for composite configuration (average period to reangiogram 35 months).

\section{FOLLOW - UP STUDIES}

Since the 1990s, several authors have demonstrated encouraging mid-term as well as long-term results of the RA conduit in coronary artery bypass surgery. $7,10,45,47$

The most essential data for mid-term studies (average period to reangiogram up to four years) are presented in table 1. Mid-term angiographic RA conduit patency varies between $90.6 \%$ to $99 \%{ }^{48,46}$ (excluding manuscripts presented by Khot ${ }^{50}$ and by Zacharias ${ }^{51}$ ) and the percentage of grafts followed up with angiography varies from $4.5 \%$ to $78.4 \%{ }^{48,43}$ However, these encouraging data must be interpreted with caution. Almost all the data (excluding manuscript by Desai ${ }^{43}$ ) are from retrospective, nonrandomized studies, and, unfortunately, lack sufficient scientific rigor to allow meaningful conclusion to be drawn, as evidence-based medicine mandates the prospective randomised trials as the most accurate tool for determing a treatment benefit compared with a control population. ${ }^{52}$

A note of caution has recently come from Clevelend Clinic in a form of retrospective, symptom-directed angiographic study on RA graft patency, presented by Khot et colleagues. ${ }^{50}$ At average follow-up of $1.6 \pm 1.4$ years RA grafts had a patency rate of $51.3 \%$, which was significantly lower than that of LITA $(90.3 \%, \mathrm{P}<0.0001)$ or saphenous vein grafts $(64.0 \%, \mathrm{P}=0.0016)$. Although their methodology is flawed (primarily because the sample studied is composed exclusively of patients presenting with angina), the article presents one of the largest angiographic follow-up studies of the RA conduit patency from a high volume Centre that has traditionally promoted arterial grafting. The importance of the manuscript is that it raises concerns about high RA graft failure at a time when the RA conduit use is increasing.

Unfortunately, propensity score statistical technique 53 (used to overcome most of the bias sources of nonmatched studies) was employed only in the manuscript of Zacharias et colleagues. ${ }^{51}$ Although cumulative 0 to 6year survival was better for radial patients (vs patients with Svg as second conduit), the angiographic RA conduits patency $(1.8 \pm 1.4$ years to reangiogram $)$ were $68.2 \%$, statistically not better than Svg patency rate $(63.3 \%)$. Low patency rates may stem in part from the fact that the patency data were derived from symptomatic patients exclusively, who reflected a worst-case scenario.
Due to possibility of silent graft occlusion, the assumption that symptom-free patients are likely to have more patent grafts does not justify extrapolation of better patency rates to entire cohort.

Neither in the article of Shah and associates ${ }^{48}$ (average period to reangiogram, again in symptomatic patients, 3.0 \pm 2.0 years) the RA conduit didn't achieve better pa-tency rate over Svg $(90.6 \%$ vs $88.9 \%)$, thus they stated "When additional grafts are required, there is no evidence to suggest that either the radial artery or saphenous vein is superior."

The well-designed prospective, randomised trial (RAPS - Radial Artery Patency Study) comparing the patency of saphenous-vein grafts with that of RA grafts has recently been reported by Desai et colleagues. ${ }^{43}$ The radial artery was randomly assigned to bypass the major vessel in either the right coronary territory or the circumflex territory, with the saphenous vein graft used for the opposing territory (control). The target coronary vessels had to be at least $1.5 \mathrm{~mm}$ in diameter, with proximal lesions causing narrowing of at least $70 \%$ of the diameter. The primary end point was graft occlusion, determined by angiography 8 to 12 months postoperatively. The angiographic study performed one year after surgery (average period to reangiogram $0.9 \pm 0.4$ years) in this trial demonstrated an occlusion rate of $8.2 \%$ for RA conduits and $13.6 \%$ for saphenous-vein grafts $(\mathrm{P}=0.009)$. However, $7 \%$ of RA grafts (versus only $0.9 \%$ of Svg) had diffuse angiographic narrowing (the "string sign"), resulting in a total "bad graft" rate of $15.2 \%$ for RA conduit (vs. $14.5 \%$ for Svg). Perfect graft patency, defined as grafts with TIMI (Thrombolysis In Myocardial Infarction) flow grade 3, was similar $(87.7 \%$ vs. $85.7 \%, \mathrm{P}=0.37)$. The long-term patency (5 to 10 years) of the RA relative to Svg grafts will be assessed in follow-up studies.

The most essential data for long-term studies (average period to reangiogram 5 or more years) are presented in table 2 .

Long-term angiographic RA conduit patency varies between $82.8 \%$ to $97.4 \%{ }^{7,8}$, and the percentage of grafts followed up with angiography varies from $5.5 \%$ to $32.9 \%$. $^{7,8}$

In a retrospective study of Cameron and colleagues9 (only 50 asymptomatic patients were included) the RA graft patency was $88.7 \%$ versus $91.7 \%$ patency rate of saphenous vein graft (average period to reangiogram 5.2 years). In addition, in a group of 21 patients who underwent restudy coronary angiography due to recurrent angina the same patency rate for the RA conduit $(88 \%)$ has been found. Therefore authors concluded that the patency rate of $89 \%$ for RA conduit might be a true reflection of patency rate for entire cohort. Unfortunately, authors have overlooked the fact that average period to restudy angiogram was only 2.7 years in symptomatic patients (thus, in all appearance, additional graft failure can be expected in next 2.5 years).

Excellent long-term patency rate have been reported by Possati and colleagues in two prospective trials. In the first one, ${ }^{49}$ the RA graft patency ( $\cong 5$ years to reangiogram) have been presented to be better than saphe- 
nous vein graft patency $(88.6 \%$ vs. $74.0 \%$, respectively, $\mathrm{P}<0.4)$. In the second one, ${ }^{10}$ the RA conduit patency $(\cong 9$ years to reangiogram) have been established to be significantly better than saphenous vein graft patency $(90.5 \%$ vs. $67.1 \%$, respectively, $\mathrm{P}<0.0001$ ), and not worse compared to ITA conduit patency $(90.5 \%$ vs. $96.3 \%$, respectively, $\mathrm{P}=0.23$ ).

The RAPCO (Radial Artery Patency and Clinical Outcome $)^{8}$ study was undertaken to compare elective angiographic patency and cardiac event-free survival of the radial artery conduit with that of the free right internal thoracic artery (Frita) or saphenous vein grafts during a 10year period after primary CABG surgery. In this prospective, randomised, single-centre trial, the RA was compared with the Frita in a younger patient group, and with Svg in an older patient group (age $\geq 75$ years). The trial conduit was grafted to the largest available coronary artery (diameter at least $1.5 \mathrm{~mm}$, proximal stenosis of at least $70 \%$ ) other than the LAD. Protocol-directed angiography at 5 years didn't support the hypothesis that the RA has superior patency (RA vs. Frita - 97.4\% vs. 100\%: RA vs. Svg $-87.5 \%$ vs. $95.5 \%$ ) to or is associated with fewer clinical events than free right internal thoracic artery or saphenous vein grafts. It has to be underlined that Svg patency appears superior to that of recorded previously, suggesting that the choice of a large target artery and factors used to protect grafts (vasodilators and 3-hydroxy-3methylglutaryl coenzyme A reductase inhibitors), may have improved the outcomes of both, the control and study grafts.

\section{THE FUTURE OF THE RADIAL ARTERY CONDUIT}

The radial artery conduit is becoming increasingly popular (due to excellent patency rates in some mid and long-term studies) as a third arterial conduit in association with LITA and RITA, or as the second in patients with contraindications to bilateral ITA harvesting. However, it is essential not to overlook the notes of caution coming from some reports (i.e. Khot and Zacharias) as these results of radial artery patency are not as expected.

The most important data are still to come. If angiographic studies between 5 and 10 years after CABG surgery show that radial artery conduits are not subject to late graft failure, they will represent an improvement over saphenous vein conduits. If the long-term patency of radial artery conduit is shown to approach the patency rates of right internal thoracic artery (RITA) grafts, radial artery conduit are likely to be substitute for RITA grafts as well as for saphenous vein grafts in the future of CABG surgery.

\section{REZIME}

Hirurška revaskularizacija miokarda je standardna procedura $\mathrm{u}$ tretmanu uznapredovale koronarne bolesti. Dokazano je da koronarna hirurgija uklanja simptome i produžava život odredjenih kategorija koronarnih bolesnika. Dugotrajni rezultati hirurške revaskularizacije miokarda u velikoj meri ovise o promenama koje se vremenom javljaju na upotrebljenom graftu. Studije dugoročnog praćenja operisanih bolesnika potvrdile su izuzetan kvalitet $\mathrm{i}$ prednost grafta unutarnje torakalne arterije u odnosu na venski graft. U skorije vreme obnovljeno je intereso-vanje za graft radijalne arterije, sa uverenjem da će njego-va primena omogućiti bolje dugoročne rezultate. U poslednje vreme prikazani su radovi koji potvrdjuju izu-zetnu kratkoročnu i dugoročnu prohodnost grafta radijalne arterije $\mathrm{i}$ govore $\mathrm{u}$ prilog intenzivnije primene toga grafta $\mathrm{u}$ hirurškoj revaskularizaciji miokarda. $\mathrm{Na}$ prikaz je pregled sadanjih saznanja o radijalnoj arteriji kao graftu $\mathrm{u}$ kardiohirurgiji, sa posebnim osvrtom na kliničke rezultate.

Ključne reči: hirurška revaskularizacija miokarda, graftovi, radijalna arterija

\section{REFERENCE}

1. Taggart D, D'Amico R, Altman D. Effect of arterial revascularisation on survival: a systematic review of studies comparing bilateral and single internal mammary arteries. Lancet 2001; 358: 870-5.

2. Fitzgibbon G, Kafka H, Leach A, Keon W, Hooper G, Burton J. Coronary bypass graft fate and patient outcome: angiographic follow-up of 5065 grafts related to survival and reoperation in 1388 patients during 25 years. J Am Coll Cardiol 1996; 28(3): 616-26.

3. Nwasokwa O. Coronary artery bypass graft disease. Ann Intern Med. 1995; 123(7): 528-33.

4. van Brussel L, Voors A, Ernst G, Knaepen J, Plokker M. Venous coronary artery bypass surgery: a more than 20-year follow-up study. Eur Heart J. 2003;24(10):92736.

5. Lytle B, Blackstone E, Loop F, Houghtaling P, Arnold J, Akhrass R, et al. Two internal thoracic artery are better than one. J Thorac Cardiovasc Surg 1999; 117 : 855-72.

6. Lytle B, Blackstone E, Sabik J, Houghtaling P, Loop F, Cosgrove D. The effect of bilateral internal thoracic artery grafting on survival during 20 postoperative years. Ann Thorac Surg 2004; 78: 2005-14.

7. Acar C, Ramsheyi A, Pagny J-Y, Jebara V, Barrier P, Fabiani J-N, et al. The radial artery for coronary artery bypass grafting: clinical nad angiographic results at five years. J Thorac Cardiovasc Surg 1998;116: 981-9.

8. Buxton B, Raman J, Ruengsakulrach P, Gordon I, Rosalion A, Bellomo R. Radial artery patency and clinical outcomes: five-year interim results of a randomized trail. J Thorac Cardiovasc Surg 2003; 125: 1363-71.

9. Cameron J, Trivedi S, Stafford G, Bett JHN. Fiveyear angiographic patency of radial artery bypass grafts. Circulation 2004; 110 Šsuppl IIĆ: II-23 - II-26.

10. Possati G, Gaudino M, Prati F, Alessandrini F, Trani C, Glieca F, et al. Long-term results of the radial artery used for myocardial revascularisation. Circulation 2003; 108: $1350-4$.

11. Carpantier A, Guermonprez J, Deloche A, Frechette $\mathrm{C}$, DuBost $\mathrm{C}$. The aorta-to-coronary radial artery bypass graft. A technique avoiding pathological changes in grafts. Ann Thorac Surg 1973; 16: 111-21.

12. Acar C, Jebara V, Potroghese M, Beyssen B, Pagny $\mathrm{J}$, Grare $\mathrm{P}$, et al. Revival of the radial artery for coronary artery bypass grafting. Ann Thorac Surg 1992; 54: 6529. 
13. Moon M, Barner H, Bailey M, Lawton J, Moazami $\mathrm{N}$, Pasque $\mathrm{M}$, et al. Long-term neurologic hand complications after radial artery harvesting using conventional cold and harmonic scalpel techniques. Ann Thorac Surg 2004; 78: 535-8.

14. Verma S, Szmitko P, Weisel R, Bonneau D, Latter D, Errett L, et al. Should radial arteries be used routinely for coronary artery bypass grafting ? Circulation 2004; 110: e40-6.

15. Parolari A, Rubini P, Alamanni F, Cannata A, Xin W, Gherli T, et al. The radial artery: which place in coronary operation? Ann Thorac Surg 2000; 69: 1288-94.

16. Amano A, Takahashi A, Hirose H. Skeletonized radial artery grafting: improved angiographic results. Ann Thorac Surg 2002; 73: 1880-7.

17. Aguero O, Navia JL, Navia JA, Mirtzouian E. A new method of myocardial revascularisation with the radial artery. Ann Thorac Surg 1999; 67: 1817-8.

18. Jo WM, Na CY, Baek MJ, Oh SS. Application of Cabrol technique to off-pump coronary artery bypass grafting using radial artery. Ann Thorac Surg 2004; 78: 1081-2.

19. He Gw. Arterial grafts for coronary bypass grafting: biological characteristics, functional classification and clinical choice. Ann Thorac Surg 1999; 67: 277-84.

20. Zimmerman P, Chin E, Laifer-Narin S, Ragavendra N, Grant E. Radial artery mapping for coronary artery bypass graft placement. Radiology 2001; 220: 299-302.

21. Mansurodlu D, Ömerodlu S, Göksedef D, Yzgi A, Kirali K, Ypek G, et al. Does radial artery harvesting cause any changes in the forearm circulation during the postoperative period ? An angiographic study - Original investigation. Anadolu Kardiyol Derg 2004; 4: 149-52.

22. Royse A, Royse C, Maleskar A, Garg A. Harvest of the radial artery for coronary artery surgery preserves maximal blood flow of the forearm. Ann Thorac Surg 2004; 78: 539-42.

23. Royse A, Royse C, Shah P, Williams A, Kaushik S, Tatoulis J. Radial artery harvest technique, use and functional outcome. Eur J Cardiothorac Surg 1999;15:18693.

24. Greene M, Malias M. Arm complications after radial artery procurement for coronary bypass operation. Ann Thorac Surg 2001; 72: 126-8.

25. Lee H-S, Heo Y-J, Chang B-C. Long-term digital blood flow after radial artery harvesting for coronary artery bypass grafting. Eur J Cardiothorac Surg 2005; 27: 99-103.

26. Agrifoglio M, Dainese L, Pasotti S, Galanti A, Cannata $\mathrm{A}$, Roberto $\mathrm{M}$, et al. Preoperative assessment of the radial artery for coronary artery bypass grafting: is the clinical Allen test adequate ? Ann Thorac Surg 2005; 79: 570-2.

27. Mensah JN. An unexpected complication after harvesting of the radial artery for coronary artery bypass grafting. Ann Thorac Surg 1998; 66: 929-31.

28. Fox AD, Whiteley MS, Hughes JP, Roake J. Acute upper limb ischemia: a complication of coronary artery bypass grafting. Ann Thorac Surg 1999; 67: 535-7.
29. Patel A, Henry C, Hunnicut C, Cockerham C-A, Willey B, Urschel H, Jr. Endoscopic radial artery harvesting is better than the open technique. Ann Thorac Surg 2004; 78: 149-53.

30. Casselman FP, La Meir M, Cammu G, Wellens F, De Geest R, Degrieck I, et al. Initial experience with an endoscopic radial artery harvesting technique. J Thorac Cardiovasc Surg 2004; 128: 463-6.

31. Oshima A, Takeshita S, Kozuma K, Yokoyama N, Motoyoshi K, Ishikawa S, et al. Intravascular ultrasound analysis of the radial artery for coronary artery bypass grafting. Ann Thorac Surg 2005; 79: 99-103.

32. Chowdhury U, Airan B, Mishra P, Kothari S, Subramaniam G, Ray R, et al. Histopathology and morphometry of radial artery conduits: basic study and clinical application. Ann Thorac Surg 2004; 78: 1614-22.

33. Gaudino M, Tondi P, Serricchio M, Spatuzza P, Santoliquido A, Flora R, et al. Atherosclerotic involment of the radial artery in patients with coronary artery disease and its relation with midterm radial artery graft patency and endothelial function. J Thorac Cardiovasc Surg 2003; 126:1968-71.

34. van Son JA, Smedts F, Vincent JG, van Lier, Kubat $\mathrm{K}$. Comparative anatomic studies of various arterial conduits for myocardial revascularisation. $\mathrm{J}$ Thorac Cardiovasc Surg 1990; 99: 703-7.

35. Mussa S, Choudhary B, Taggart D. Radial artery conduits for coronary artery bypass grafting: Current perspective. J Thorac Cardiovasc Surg 2005; 129: 250-3.

36. He GW, Yang CQ. Radial artery has higher receptor-mediated contractility but similar endothelial function compared with mammary artery. Ann Thorac Surg 1997; 63: 1346-52.

37. Mussa S, Guzik T, Black E, Dipp M, Channon K, Taggart D. Comparative efficacies and durations of action of phenoxybenzamine, verapamil/nitroglicerin solution, and papaverine as topical antispasmodics for radial artery coronary bypass grafting. J Thorac Cardiovasc Surg 2003; 126: 1798-805.

38. Cable DG, Caccitolo JA, Pearson PJ, O'Brien T, Mullany C, Daly RC, et al. New approaches to prevention and treatment of radial artery graft vasospasm. Circulation 1998; 98(Suppl II): II 15-II 22.

39. Gaudino M, Glicea F, Luciani N, Alessandrini F, Possati G. Clinical and angiographic effects of chronic calcium channel blocker therapy continued beyond first postoperatice year in patients with radial artery grafts: results of a prospective randomized investigation. Circulation 2001; 104 (Suppl I): I 64- I 67.

40. Gaudino M, Luciani N, Nasso G, Salica A, Canosa C, Possati G. Is postoperative calcium channel blocker therapy needed in patients with radial artery grafts ? J Thorac Cardiovasc Surg 2005; 129: 532-5.

41. Maniar H, Sundt T, Barner H, Prasad S, Peterson L, Absi T, et al. Effect of target stenosis and location on radial artery patency. J Thorac Cardiovasc Surg 2002; 123 : 45-52.

42. Maniar H, Barner H, Bailey M, Prasad S, Moon M, Pasque $\mathrm{M}$, et al. Radial artery patency: are aortocoronary 
conduits superior to composite grafting ? Ann Thorac Surg 2003; 76: 1498-504

43. Desai N, Cohen E, Naylor D, Fremes E. A randomized comparison of radial-artery and saphenous-vein coronary bypass grafts. N Eng J Med 2004; 22: 2302-9.

44. Al-Ruzzeh S, Modine T, Athanasiou T, Mazrani W, Azeem F, Nakamura K. Can the use of the radial artery be expanded to all patients with different surgical grafting techniques? Early clinical and angiographic results in 600 patients. J Card Surg 2005; 20: 1-7.

45. Iaco AL, Teodori G, Di Giammarco G, Di Mauro M, Storto L, Mazzei V, et al. Radial artery for miocardial revascularisation: long-term clinical and angiographic results. AnnThoracSurg 2001; 72: 464-8.

46. Calafiore AM, DiMauro M, D’Alessandro S, Teodori G, Vitolla G, Contini M, et al. Revascularisation of the lateral wall: long-term angiographic and clinical results of radial artery versus right internal thoracic artery grafting. J Thorac Cardiovasc Surg 2002; 123: 225-31.

47. Bhan A, Gupta V, Choudhary SK, Sharma R, Singh B, Aggarwal R, et al. Radial artery in CABG: could the early results be comparable to internal mammary artery graft? Ann Thorac Surg 1999; 67:1631-6.

48. Shah P, Bui K, Blackmore S, Gordon I, Hare D, Fuller J, et al. Has the in situ right internal thoracic artery been overlooked? An angiographic study of the radial artery, internal thoracic arteries and saphenous vein graft patencies in symptomatic patients. Eur J Cardiothorac Surg 2005; 27: 870-5.

49. Possati G, Gaudino M, Alessandrini F, Luciani N, Glieca F, Trani C, et al. Midterm clinical and angiographic results of radial artery grafts used for myocardial revascularisation. J Thorac Cardiovasc Surg 1998; 116: 1015-21.

50. Khot U, Friedman D, Petterson G, Smedira N, Li J, Ellis S. Radial artery bypass grafts have an increased occurence of angiographically severe stenosis and occlusion compared with left internal mammary arteries and saphenous vein grafts. Circulation 2004; 109: 2086-91.

51. Zacharias A, Habib R, Schwann T, Riordan C, Durham S, Shah A. Improved survival with radial artery versus vein conduits in coronary bypass surgery with left internal thoracic artery to left anterior descending artery grafting. Circulation 2004; 109: 1489-96.

52. Pocock SJ, Elbourne DR. Randomized trials or observational tribulations? N Eng J Med 2000;342:1907-9.

53. Blackstone EH. Comparing apples and oranges. J Thorac Cardiovasc Surg 2002; 123: 8-15. 